\title{
XIX. Yüzyıl Başları Üsküdar'ında Ekonomik ve Toplumsal Bir Güç Olarak Yeniçeriler
}

\author{
Mehmet Mert SUNAR*
}

Öz

Bu çalışmada XIX. yüzyıl başları İstanbulunda siyasi, sosyal ve ekonomik hayatında baskın bir aktör olan yeniçerilerin Üsküdar'da iz bırakmış olan faaliyetleri incelenecektir. Yeniçerilerin ekonomik menfaatleri ve sosyal statülerini korumak amacı ile siyaseti etkileme çabaları doğrultusunda Sultan III. Selim ve Sultan II. Mahmud devirlerinde gerçekleşen Kabakçı Mustafa İsyanı, Alemdar Vakası ve son olarak da yeniçeriliğin kaldırılması sırasındaki faaliyetlerinin Üsküdar'daki yansımaları çalışmanın odak noktasını oluşturacaktır. Yeniçerilerin on yedinci yüzyıldan itibaren askerlik mesleğinin yanı sıra ticaret ve zanaatlar ile uğraşmaya başlaması İstanbul'un bütün semtleri gibi Üsküdar'ı da etkilemiş, Üsküdar'da nakliye işlerinden deri imalatına, kahvehane işletmeciliğinden kasaplığa kadar pek çok iş alanında çalışanlar arasında yeniçeri kökenliler önemli bir yer işgal etmeye başlamıştı. Bu durum on dokuzuncu yüzyıl başlarına kadar artarak devam etmişti. Nizam-1 Cedid reformları ile başlayıp 1826'da Yeniçeriliğin kaldırılması ile devam eden askeri reform çabaları yeniçeriler ile birlikte farklı halk tabakalarını da tehdit ettiğinden Üsküdar'da da bazen şiddete varan tepkilere yol açmıştı. Bütün payitahtı etkileyen ve Üsküdar'da yansımaları görülen bu olayların Üsküdar'daki yeniçeri varlığı ile olan iliş̧isi de bu çalışmanın bir diğer konusunu oluşturmaktadır.

Anahtar Kelimeler: Yeniçeri Ocağı, Üsküdar, Vaka-i Hayriye, Kabakçı Mustafa İsyanı, Alemdar Vakası.

\footnotetext{
* Doç. Dr., İstanbul Medeniyet Üniversitesi, Tarih Bölümü, İstanbul, Türkiye. Elmek: mehmet.sunar@medeniyet.edu.tr https://orcid.org/0000-0003-0971-9612.
} 


\title{
Janissaries as a Socio-Economic Force in Nineteenth Century Üsküdar
}

\begin{abstract}
This study examines the activities of janissaries in Üsküdar district of Istanbul in the beginning of the nineteenth century. As in other parts of Istanbul, janissaries were important actors in political and socioeconomic life of Üsküdar district. The present paper will focus on the relation between the janissary efforts to protect their economic interests as well as their social status and their roles in important political events of the reigns of Sultan Selim III and Sultan Mahmud II such as the Rebellion of Kabakçı Mustafa and the so-called Alemdar Incident. Involvement of janissaries in trade and crafts from the seventeenth century forward also affected the daily life of Üsküdar and increased the presence of artisans, daily wageworkers and merchants with janissary connections. As a result, these janissary artisans came to occupy a dominant position among various trades and crafts from transportation and construction sectors to coffeehouse ownership and leather production in the early nineteenth century. Starting with the New Order of Sultan Selim III, the efforts the central government to reform the military and the existing social order threatened janissaries as well as certain status groups in the society. This paper also focuses on the reactions of these groups and their results in the case of Üsküdar till the abolition of the Janissary Corps and its immediate aftermath.
\end{abstract}

Keywords: Janissary Corps, Üsküdar, Kabakçı Mustafa Rebellion, The Auspicious Event, Alemdar Incident. 


\section{Extended Summary}

As in many districts of Istanbul before 1826, janissaries played an important role in political, social and economic life of Üsküdar. This paper aims to draw a general picture of janissary activities in early nineteenth century Üsküdar with a specific focus on janissary opposition to the military reforms of Sultan Selim III and Mahmud II. It is very easy to trace the evidence on Janissary presence in crafts and commerce in daily life of late eighteenth and early nineteenth century Üsküdar. From transportation sector to small merchants, livestock traders to coffeehouse owners, janissaries occupied a central place in economic and social life in Üsküdar as they did in other districts of Istanbul.As expected, janissary laborers and artisans jealously tried to protect their interests and privileges against any encroachments.

Even though they were often successful against rival craftsmen and artisans in their struggle, the military reforms of the late eighteenth and early nineteenth centuries pitched a more formidable adversary against janissaries, namely the centralizing state. As janissaries were quite aware that the newly proposed system of military training and drill would eventually force them to give up their commercial and artisanal activities.

Immigration from provinces to the Ottoman capital provided necessary manpower for the Janissary Corps. In that sense, regional identities mixed with communal identity of the Janissary Corps played an important role in providing social support for janissaries in their struggle for political influence. It is also possible to observe this in the case of the janissaries of Üsküdar.

The practice of dividing the districts and commercial centers of Istanbul into zones of influence among janissary regiments was also valid for Üsküdar. As the wharf of Üsküdar was under the control of the 59th Ağa Bölük of the Janissary Corps in the early nineteenth century, an attempt by the infamous 25 th Cemaat to challenge this control resulted in a short period of violence between these two regiments in Üsküdar. However, such divisions were temporary and liable to disappear when general interests of the Janissary Corps were at risk 
such as in the case of threat posed by Grand Vizier Alemdar Mustafa Pasha's government. In 1808, all the janissaries and their civilian supporters united against Alemdar's forces and attacked the Selimiye Barracks, the center and main symbol of military reform in Üsküdar. In the event, a crowd of janissaries and civilians happily pillaged and burned down this symbol to the ground.

However, the program of military reform was not tied to a particular Sultan, Grand Vizier or even a cadre of bureaucrats; it was a long-term plan of the newly rising bureaucracy, which considered the military and bureaucratic reforms vital against the international challenges that the Ottoman Empire faced in the late eighteenth and early nineteenth century. It was not surprising that the military reform program returned with a vengeance once again in 1826. This time the janissaries were helpless to stop Sultan Mahmud II's government and their resistance lasted surprisingly short.

Although Sultan Mahmud II's government was successful in abolishing the Janissary Corps easier than it expected, it was afraid of new attempts to revive the Corps by janissary elements deep rooted in Istanbul's population. It even acted in a quite paranoid manner in the following years and this attitude also influenced Üsküdar's population. For instance, the government officials claimed that they unearthed a janissary plot during the Ottoman-Russian War of 1828-1829. They arrested some Bektashis and former janissaries in different parts of Istanbul and questioned them about the alleged plot. There were several residents of Üsküdar among the accused showing that janissary presence were still continuing in Üsküdar despite harsh and relentless suppression of janissary identity by Sultan Mahmud II's government. 


\section{Giriş}

1826 öncesi İstanbul'unun pek çok semtinde olduğu gibi Üsküdar'da da yeniçeriler dikkate alınması gereken toplumsal ve ekonomik bir gücün üyeleri olarak günlük yaşamın önemli aktörleriydi. Bu yaşamın kalıntıları olarak günümüze kalan vakayinameler, mahkeme sicilleri ve devlet belgelerinde Üsküdar'da yeniçerilerin bıraktığı izleri takip etmek mümkündür. Bu tebliğde XIX. yüzyıl başları Üsküdar'ında kendini yeniçeri olarak tanımlayan grupların toplumsal ve ekonomik hayattaki etkisi üzerinde genel biçimde durulacak, ancak asıl olarak siyasi olarak son derece çalkantılı olan bu dönemde yeniçerilerin ve onları destekleyen grupların isyan ve adli vakalarda oynadıkları role odaklanılacaktır.

Öncelikle dönemin bazı kaynaklarında bir mahalde yeniçerilerin varlığı ve etkisinin ne kadar derin olduğunu belirtmek için kullanılan "yeniçeri şehri" tabirini Üsküdar'a uygulayıp, Üsküdar için de bir “yeniçeri semti” demek abartılı bir ifade olmayacaktır. Üsküdar'ın kıyılarındaki iskeleler, bekâr odaları ve kayıkhanelerden semtin merkezindeki alış-veriş mekânlarına, oradan semtin dış bölgelerindeki bahçe, bostan ve kırlıklara kadar yayılan bir alan içinde yeniçeriler Üsküdar hayatının sıradan ve normal bir parçasıydı. Buralarda yaşayan ve çalışan kayıkçılar, hamallar, seyyar satıcılar, çeşitli esnaf grupları, bahçe ve bostanlarda üretimle meşgul olanlar ya da İstanbul'a yakın bölgelerden canlı hayvan getirenlerin hatırı sayılır bir kesimi ya kendini yeniçeri olarak tanımlamakta ya da Yeniçeri Ocağı ile bir ünsiyet iddiasında bulunmaktaydı. XIX. yüzyıl başlarındaki reform süreci sebebi ile devlet belgelerinde ve ricale mensup ya da tâbi kesimler tarafindan üretilen metinlerde son derece olumsuz tasvirlerle yâd edilseler de yeniçerilerin XVII. yüzyıldan itibaren Osmanlı şehirlerinin dokusunun önemli üyeleri olduğunu unutmamamız gereklidir. Bu sebeple kendimizi kaynakların yönlendirmesine çok fazla kaptırmamalı ve bu kaynaklarda neredeyse yabancı bir doku ya da alınması gereken habis bir ur gibi tasvir edilen bu insanların Osmanlı toplumunun birer üyesi olduğunu hatırda bulundurmalıyız.

Aslında XIX. yüzyıl başları Üsküdar'ında yukarıda tanımladığımız yeniçeri varlığı İstanbul' da XVII. yüzyılda ivme kazanan bir sürecin sonucuydu. Yeniçerile- 
rin devamlı atıfta bulunmayı çok sevdikleri kanun-ı kadimlerine göre vazifeden affedilip "emekli" olana kadar toplum içine karışmamaları gerekirken, hem devşirme sisteminin tedricen ortadan kalkarak Müslüman ahaliden yeniçeri yazılması hem de iktisadi koşullar sebebi ile kanun-1 kadimin bu kuralının unutulduğu görülmektedir. Hem evlenip aile kurarak hem de askerlik dişındaki işlerle meşgul olarak toplumsal hayatın içine girerek derin ilişki ağlarının bir parçası haline gelen yeniçeriler her ne kadar hala kendilerine hünkârın "kulu" deseler de artık bu statünün gerektirdiği yükümlülükleri yerine getirmekte giderek daha isteksiz biçimde davranacaklardı. Bu açıdan çoğu devşirme kökenli olan XVII. yüzyıl layiha yazarlarının biraz da grup psikolojisi ile karşı çıktıkları reaya ve şehirli "oğullarının” Ocağa yazılmasının disiplini bozduğu tespitinde doğruluk payı vardı. (Ünver 1969: 25) İlk başlarda çoğunlukla cebir kullanarak kendilerine üretim ve ticaret hayatında bir yer açan yeniçeri "esnafı", giderek dışarıdan müdahil olduğu bu dokunun bir parçası haline gelecek ve XVIII. yüzyıla gelindiğinde yeniçerilerin esnaflı̆̆ anormal bir durum olmaktan çıkacaktı. İşte XIX. yüzyıl başları kaynaklarında Üsküdar'da karşımıza çıkacak olan yeniçeri hamallar, kayıkçılar ve çok farklı alanlarda faaliyet gösteren yeniçeri esnafı bu sürecin bir sonucuydu.

Diğer bir taraftan Yeniçeri Ocağı'nın saflarının doğuştan Müslüman gruplara açılması özellikle İstanbul'a göç ile gelen ve iş arayan kimseler için statü değiştirmenin ve aldığı ulufe ne kadar düşük olursa olsun bir "dirlik" sahibi olmanın kapısını açmıştı. Anadolu'dan İstanbul'a gelen göçmenlerin ilk ayak bastığ İstanbul beldesi olan Üsküdar bu kesimden önemli bir nüfusu da barındırmaktaydı. Bu kesimin bir kısmı için yeniçeri statüsü kazanabilmenin önemli bir yolu ya Ocak üyesi olan hemşerilerinin ya da farklı biçimlerde iş ilişkisine girdikleri esnaf yeniçerilerin aracılığıydı. Bunların bir kısmı Ocağa giremese de yeniçerileri ile kurdukları ünsiyet sebebi ile yeniçerilik tasladıkları için "taslakçı" olarak adlandırılmaktaydı.

Yukarıda anlatılan bu tablo esasta Osmanlı hanedanının sürekli profesyonel asker beslemek için kurduğu yeniçeri sisteminin XVIII. yüzyıla gelindiğinde bu amacın ötesinde anlamlar kazanarak çok daha farklı toplumsal işlevler kazandığının göstergelerinden biriydi. Bu açıdan yeniçeriliğin Osmanlı Devleti'nde bir sosyal güvenlik sistemini dönüştüğü tespitinde haklılık payı bulunmaktaydı. 
(Aksan 2007: 52) XVIII. yüzyıl sonlarında Osmanlı ricalinin artık iyice kanaat getirdiği gibi Yeniçeri Ocağı'nın devletin iç ve dış rakiplerine karşı güvenliğini sağlayacak bir zor kullanma aracı olmaktan çıkmış olması Nizâm-1 Cedîd gibi bir projenin husule gelmesinin temel sebebiydi. Nizâm-1 Cedîd projesinin ortaya çıkışındaki tartışmaların gösterdiği gibi her ne kadar Osmanlı ricalinin büyük bir kısmı yeniçerilerin temsil ettiği toplumsal ve siyasi gücü karşısına almayı halen göze alamıyorsa da Bostanî Tüfekçileri adı altında kamufle edilmeye çalışan yeni orduya ilk başlarda yeniçerilerden sert bir tepkinin gelmemesi rical arasındaki reformcu kanadı cesaretlendirmiş olmalıdır. Bir taraftan yeniçerilerin 1787-1792 Harbi'nde Osmanlı ordularının ve kendi ocaklarının özellikle Rus cephesindeki gösterdiği kötü performansın henüz hafizalarda olması dolayısı ile reform çabalarına tepki göstermekte tereddüt ettikleri düşünülebilir. Diğer bir taraftan yeni teşkil edilmekte olan Nizâm-1 Cedîd birliklerinin insan kaynağının yeniçerilerle aynı olması, hatta bir kısım yeniçerilerin ek gelir elde etmek amacı ile bu birliklere yazılması bu tepkisizliği açıklayan bir diğer etkendir.

Yeniçerilerin Nizâm-1 Cedîd askerlerine ve yeni reform projesine karşı yönelttikleri ilk ciddi tehdit, 1805 yılında Selimiye Kışlası yanında inşası biten Selimiye Cami'nin III. Selim tarafından cuma selamlığı töreni ile açılması hazırlıkları sırasında meydana geldi. Selamlık töreninde mutad olduğu üzere yeniçerilerin değil Nizâm-ı Cedîd askerlerinin yer alacağının ilanı üzerine Üsküdar'da silahlar1 ile birlikte toplanan yeniçerilerin sergilediği saldırgan davranışlar ve Nizâm-1 Cedîd askerlerini ortadan kaldıracakları tehdidi üzerine geri adım atılmış, cuma selamlığının ertelendiği ve sonra gerçekleştirilecek törende de yeniçerilerin yer alacağı ilan edilerek ortalık yatıştırılabilmişti. (Yıldız 2008: 121-122) Ancak bu olaya karşın Üsküdar'da ne 1807'deki Kabakçı İsyanı'na değin ne de isyan sırasında Nizâm-1 Cedîd askerine karşı yeniçeriler tarafından bir hareket vuku bulmamıştı. Aynı şekilde yeni reformların kurumsal ve sembolik olarak nişanesi olan Selimiye Kışlası'na karşı da bir harekete girişilmemişti. Bu sırada sadece sembolik anlamı olan bir hareketle kışla kapısı üzerinde padişahın kışlayı ziyaretlerinde konaklaması için inşa edilen köşk yıktırılmıştı. (Câbî Târîhi 2003: c. I, 229-230)

Ancak Kabakçı İsyanı sonrası İstanbul'unda asayişin yeniden sağlanabilmesi için IV. Mustafa'nın kısa sürecek saltanatı sırasında bazı önlemler alınmaya 
çalışılmıştı. Bu önlemler kapsamında olmak üzere şehir dâhilinde silah taşıma yasağı getirilmiş ve İstanbul'daki bütün mahkemelere ve asayişten sorumlu görevlilere bu yasağı istisnasız biçimde uygulamaları emredilmişti. Boğaziçi'nin diğer sahilleri gibi Üsküdar sahillerinde de asayişin sağlanmasından sorumlu olan Bostancılar büyük ihtimalle tepeden gelen baskılar sonucu bu kuralları sıkı biçimde uygulamaya çalışmışlar bu da önceki dönemde daha rahat davranmaya alışmış yeniçeriler gibi kendilerini ayrıcalıklı gören sınıflarla aralarında sorunlar çıkması ile sonuçlanmıştı. İşin içine yeniçeriler arasındaki yoldaşlığa, akrabalığa ve hemşeriliğe dayalı bağlar da girince Üsküdar'da iz bırakan bazı olaylar yaşanmıştı. Örneğin Üsküdar'daki ticari hayatta önemli bir rol oynadığı belli olan Yeniçeri Ocağı'nın 59. Ağa Bölüğü'ne mensup bazı yeniçeriler İstanbul çevresindeki köylerden küçükbaş hayvan alıp Üsküdar'da satmak için getirirken Selâmiye mahallesinde silah taşıdıkları gerekçesi ile Bostancılar tarafından durdurulup silahlarına el konulup, hapsedilmek istediklerinde direniş göstermişler çıkan arbedede bir yeniçeri vurularak öldürülmüştü. Öldürülen yeniçerinin akrabalarından birinin 59. Bölüğün ileri gelenlerinden bir serdengeçti ağası olması olayın büyümesine yol açmıştı. Olaya sebebiyet veren Bostancı zabiti hasekinin Üsküdar mahkemesine sığındığını haber alan yeniçeriler mahkemeye gelerek önce naipten sonra da kadıdan davalarının görülerek hasekinin mahkûm edilmesini istemişlerdi. $\mathrm{Bu}$ taleplerinin reddi üzerine yeniçeriler Bostancı hasekisini sığındığı mahkemeden zorla alarak Üsküdar'daki yeniçeri kolluğuna götürürlerken, öldürülen yeniçerinin yakınları tarafından kasten bir kargaşa çıkarılmış ve bu sırada söz konusu Bostancı hasekisi intikam darbeleri altında son nefesini vermişti. (Câbî Târîhi 2003: c. I, 161-162) Siradan bir şiddet gösterisinin çok ötesinde olan bu olay Kabakçı İsyanı sonrası merkezi hükümetin otoritesinin sınırları konusunda önemli bir göstergeydi. Bu olay karşısında hükümetin yapabildiği sadece sefer nedeni ile İstanbul' daki en yüksek rütbeli yeniçeri zabiti olan Sekbanbaşı vasıtası ile 59. Ağa Bölüğü ortası mütevellisini tehdit ederek 59. Ağa Bölüğü’nü kontrol altına almaya çalışmaktan öteye geçememişti.

Ancak yeniçeriler ile hükümet arasındaki bu denge IV. Mustafa'nın hal' edilmesi ile değişecek, yeni sadrazam Alemdar Mustafa Paşa eli ile Nizâm-1 Cedîd'in yeniden ihya edilmesi çabaları sırasında yeniçeriler ile yeni rejimin tem- 
silcileri arasındaki mücadele giderek sertleşecekti. Sadrazamlığa getirilen Alemdar Mustafa Paşa'nın modern dönemlerin sıkıyönetim rejimlerini anımsatan idare tarzı sırasında yeniçerilere karşı sert ve aman vermeyen bir siyaset izlenmesi karŞılıklı şiddet olaylarının da artmasına yol açacaktı. Bu sert idarenin Üsküdar'daki ilk emareleri Balaban İskelesi civarında bulunan ve çoğunlukla yeniçeri Ocağı'na mensup hamalların ve kalyoncuların kaldığı bekâr odalarının peyderpey yıkılması ile ortaya çıkmıştı. ((Câbî Târîhi 2003: c. I, 196, 209) Buralarda kalanların karıştığı şiddet olayları ve işledikleri suçlar uzun süredir şikayet konusu olmasına rağmen bu konuda harekete geçilmesi ancak Nizâm-1 Cedîd'in sert biçimde yeniden ihya edilmesi çabaları sırasında mümkün olabilmişti. Diğer taraftan tabiri caizse bu örfi idarenin daha sert biçimde uygulanabilmesi amacı ile eski bir Nizâm-1 Cedîd binbaşısı olan Arnavut Bekir Ağa Üsküdar'daki bostancıların başına Üsküdar Ustası olarak atanmıştı. (Câbî Târîhi 2003: c. I, 196) Yeni Üsküdar Ustası'nın ilk icraatlarından biri Kabakçı İsyanı sonrası Üsküdar'daki olaylarda dahli olan 59. Ağa Bölüğü’nden bazı yeniçerilerin Üsküdar'da idam edilerek bu yeniçeri ortasına mensup yeniçerilere gözdağı verilmesiydi. (Georg Oğlukyan'ın Ruznamesi 1972: 37; Câbî Târîhi 2003: c. I, 198). İlerleyen günlerde kasitlı olarak asayişin sağlanması için bu tedhiş ortamı devam ettirilmiş, sadece 59. Ağa Bölüğü'ne mensup yeniçeriler değil, esnaf kethüdaları dahi Üsküdar Ustası'nın gadrinden kurtulamamış, mesela Üsküdar'daki Bitpazarı Kethüdası Hacı Mehmed Ağa önceki suçlarına binaen birkaç adamı ile birlikte idam edilip, III. Ahmed Çeşmesi'nin ibret-i âlem sergisinin gelip geçici parçalarından biri olmuştu. (Câbî Târîhi 2003: c. I, 200-201).

Üsküdar'da yaşayan yeniçeriler için Nizâm-1 Cedîd'in geri gelişini kesin olarak ilan eden diğer bir olay da kapalı bulunan Selimiye Kışlası'nın açılması, Sekban-1 Cedîd ismi verilerek yeniden kurulan birliklerin burada talime başlaması ve kışla etrafında kapalı bulunan hamam, çarşı ve dükkânların yeniden faaliyete geçirilmesiydi. Yeniçeriler açısından işi daha da vahim hale getiren Nizâm-1 Cedîd'in taşradaki önemli destekçilerinden olan ve özellikle Konya civarında yeniçerilere uyguladığı şiddet yüzünden yeniçerilerin gözünde kötü şöhrete sahip olan Kadı Abdurrahman Paşa'nın askerleri ile gelip, askerlerini Selimiye Kışlası civarında kiralanan han ve evlere yerleştirmesiydi. Askerlerin Selimiye Kışlası'na 
değil de çevredeki han ve evlere yerleşmesi kışlanın askerlerin ikametine uygun olmadığını göstermektedir. Kadı Abdurrahman Paşa'nın ikameti için de yine aynı bölgede bulunan eski sadrazamlardan İsmail Paşa'nın konağı hazırlanmıştı. Benzer biçimde Anadolu ayanlarından Cebbarzâde tarafindan Sekbân-1 Cedîd Ocağı için gönderilen askerler yine Selimiye Kışlası civarındaki hanlara ve evlere yerleştirilmişti. (Câbî Târîhi 2003: c. I, 217, 229)

Alemdar Mustafa Paşa idaresinin Yeniçeri Ocağı mensuplarına ve ocağın toplumsal dayanağının önemli bir kesimini oluşturan taşralı göçmenlere karşı tutunduğu sert tavır Üsküdar'da yaşayan gayrı Müslim reaya örneğinde olduğu gibi bazı kesimlerde sevinçle karşılansa da yeni sadrazamın merhametsizliği ve beraberindeki sekbanların tavırları yeniçerileri destekleyen kesimlerce nefret ve eleştiri konusu oluyordu. Mesela bu nefretini gizlemeyen Yayla İmamı Risalesi'nin müellifi, Alemdar'ın merhametsizliğinden ve sorgusuz sualsiz insanları idam ettiğinden bahsetmekte, sadrazamın yeniçerilerin kendine karşı bir harekete geçmesine karşı aldığ tedbirlerden bahsederken de Alemdar için "El-hainü haif" ifadesini kullanmaktaydı. (Derin 1975: 249-253) Olayların sonucunu bilmenin verdiği rahatlıkla bu patlamaya hazır öfke ve nefretin serbest kalabilmek için sadece bir kıvılcım beklediği iddia edilebilir. Fakat yanlışlanabilir olmaması sebebi ile gayet cazip olan bu tespite karşı yine dönemin kaynaklarına müracaat edilerek eğer Alemdar Mustafa Paşa idaresi birkaç ay daha devam edebilseydi Yeniçeri Ocağı'ndan bir nişan kalmayacağı iddiası da dikkate alınmalıdır. Ancak her hâlükârda Alemdar Mustafa Paşa'nın durumunun her an patlamaya hazır bir barut fiçısının üzerinde oturan birisinin durumunu andırdığı söylenmelidir.

Giderek sertleşen bir ortamda belki de can havli ile patlak veren ve tarihe Alemdar Vak'ası olarak geçen isyan bir ölüm kalım mücadelesine dönüşerek kısa süreli bir iç savaş görünümünü kazanmış, İstanbul'un diğer beldeleri gibi Üsküdar da bu şiddetten nasibini almıştı. Üsküdar'daki olayların daha büyük çaplı bir biçimde gerçekleşmemesini ise Kadı Abdurrahman Paşa'nın kumandası altındaki sekban askerinin büyük bir kısmı ile karşı yakaya sarayın yardımına koşması sağlamıştır. Sekban askerinin büyük bir kısmı ile Üsküdar'dan karşı yakaya geçen Kadı Abdurrahman Paşa, Üsküdar'da sadece Sekbân-1 Cedîd binbaşısı yapılmış olan eski Üsküdar Ustası Arnavut Bekir Ağa kumandasında 300 kadar sekban 
askeri bırakmıştı. (Georg Oğlukyan ’ın Ruznamesi 1972: 41) Üsküdar'da kalan az sayıdaki sekban askerini kumanda eden eski Üsküdar Ustası, yeni Sekbân-1 Cedîd Binbaşısı Arnavut Bekir Ağa birkaç gün boyunca İstanbul tarafından Üsküdar'a hiçbir kayığın geçmemesini sağlayarak duruma hâkim olmuştu. Bir taraftan da Üsküdar'da sorun çıkaracağı düşünülen yeniçerilerin bir kısmı çeşitli bahanelerle Selimiye Kışlası'na çağırılıp hapsedilmişti. Ancak sonunda İstanbul'daki olaylar ve Alemdarın akıbeti ile ilgili haberler Üsküdar'a ulaşmış, yeniçerilerin ve onları destekleyen grupların kolluklarda ve iskelelerde bulunan sekban askerlerine saldırmaya başlaması sonucu Arnavut Bekir Ağa kurtuluşu Selimiye Kışlası’na sığınmakta aramıştı. Üsküdar'da bulunan sekbanlara saldırmak için gelenler arasında Nizâm-1 Cedîd'in Sekbân-1 Cedîd ismi altında ihyası sürecinden ve Arnavut Bekir A ğa'dan çokça zarar gören 59. Ağa Bölüğü mensubları ile kendisi de bir yeniçeri olan müteveffa Şile Ayanı Uzun Hasan'ın yakın adamlarından Gavur İmam lakaplı sergerde komutasındaki yeniçeriler bulunmaktayd1. (Derin 1975: 257; Câbî Târîhi 2003: c. I, 291-292) İçlerinde kadınların da bulunduğu isyancılar önce kışla yakınındaki Yeni Mahalle olarak adlandırılan bölgede sekbanların kaldığı han ve evler ile Kadı Abdurrahman Paşa'nın kaldığı konağı yağmalayarak ateşe vermiş, ardından da çatışmalar ve ateş kışlaya sirayet etmiş ve burada da İstanbul'da yaşanan olaylar tekrarlanmıştı. (Şânî-zâde Târîhi 2008, c. I, 151-152; Câbî Târîhi 2003: c. I, 277, 290-294)II. Mahmud devrinde tutulan bir ruznâmede kışlaya saldıran isyancıların sayısının üç bin kişi civarında olduğu da belirtilmekteydi. (Beyhan 2007: 265) Olaylar sonucunda iki taraftan da önemli can kayıpları yaşanmış, Selimiye Kışlası ve etrafındaki dükkân ve evler büyük zarar görmüştü.

Yeniçeriler kendi müesses nizamlarına karşı yöneltilen bu ikinci Nizâm-1 Cedîd tehdidini de bertaraf etmiş olsalar da, Alemdar Vak'ası sırasında yaşanan kayıplar ve etrafa verilen zarar sebebi ile bu başarı bir Pirus zaferinden ibaretti. Bu olaylar sırasında can ve mal açısından zarar gören İstanbul halkının bir kısmının yeniçerilere olan desteklerini çekmiş oldukları düşünülmelidir. Diğer taraftan yeniçerilerin yaptığ 1 hatalardan biri de II. Mahmud'u hanedanın hayatta bulunan tek erkek üyesi olmasından dolayı hal' etmemeleriydi. Makul bir alternatifin yokluğunda tahta bırakılan Sultan II. Mahmud'un imdadına yetişen bir diğer faktör ise o dönemde hastalıklar sebebi ile bebek ölümlerinin yüksek oranı idi. 1823'te 
şehzade Abdülmecid'in doğumuna kadar II. Mahmud'un hiçbir erkek çocuğunun üç-dört yıldan fazla yaşamaması kendisine önemli bir avantaj sağlayacaktı.

Başarılı her isyan sonrasında olduğu gibi Alemdar Vak'ası'nın akabinde de belli bir süre isyancılar istedikleri gibi hareket etme serbestisi kazanmış, özellikle Üsküdar'a hâkim durumda olan 59. Ağa Bölüğü mensuplarının Alemdar Mustafa Paşa dönemindeki sert cezaların uygulanmasında rol oynayan Üsküdar'ın asayişinden sorumlu olan bostancılara karşı olan hasmane tavırları ve Üsküdar'da iş yerleri olan diğer yeniçeri ortalarının mensuplarına karşı tutumları yeni problemlere kapı aralamıştı. Yeniçeri ortaları arasında zaman zaman kurulan ittifaklar (o zamanın tabiri ile sofalarını bir etmeleri) bu durumu daha karışık hale getirecek bir faktördü. Üsküdar bostancılarının büyük bölümünün Yeniçeri Ocağı'nın 75. Cemaati'ne mensup olmaları zaruri olarak 75. Cemaatin bu duruma karışması ile sonuçlanacak, işin içine 59. Bölük mensuplarının Üsküdar'da kahve işleten 25. Cemaat'e mensup bir yeniçeriyi katletmeleri de eklenince yeniçeri ortaları arasında Üsküdar'1 altına üstüne getirecek bir çatışma kopacaktı. Aslında önceki dönemlerde de İstanbul'un bazı beldelerinde ve özellikle Galata, Karaköy ve Haliç kıyılarında yeniçeri ortaları arasında bazen günler süren çatışmaların olduğu vakiydi. 1809 yılının Haziran ayında patlak veren olaylarda 75. ve 25. Cemaatlere mensup yeniçeriler ittifak halinde oldukları 64. ve 71. Cemaatlere mensup yeniçeriler ile birlikte karşı yakadan Üsküdar'a geçip 59. Ağa Bölüğü’ne mensup yeniçerilerin kaldığı bekâr odalarına ve kahvehanelere saldırarak buraları tahrip ve yağma etmişti. Olaylar sonucunda ise 59 . Bölük mensubu bir iki yeniçeri hayatını kaybetmiş, içlerinde orta seviyeli zabitlerin de bulunduğu birçok yeniçeri yaralanmıştı. (Georg Oğlukyan'ın Ruznamesi 1972: 53).

$\mathrm{Bu}$ gibi isyan, çatışma ve şiddet olayları her ne kadar o dönem bu olaylara maruz kalan kurbanlar için talihsiz olaylar olsa da, gündelik hayatın normal akışında ortaya çıkmayan ayrıntıları ortaya çıkarıp haber değeri kazandırarak dönemin metinlerine soktukları için tarihçiler açısından talihli olaylardır. Mesela bu çatışma vasıtası ile Kartal, Gebze, Şile ve Üsküdar etrafında 71., 75. ve 25. yeniçeri Cemaat mensuplarının yoğun biçimde yaşadığını kaynaklardan öğrenebiliyoruz. Benzer biçimde bu olay sayesinde Üsküdar'ın iş ve ticaret hayatında önemli bir rol oynayan 59. Bölük ve mensupları hakkında daha detaylı bilgiler 
ediniyoruz. Tabi Üsküdar'da 59. Bölüğün iş ve ticaret hayatında oynadığı baskın rolden bahsederken Üsküdar'ın merkezinde de çevresi gibi farklı yeniçeri ortalarında mensup yeniçeri esnafının varlığını göz ardı etmemek gerekir. Örneğin Câbî Târîhi'nden suça karıştığı için hakkında bilgi edindiğimiz 52. Bölüğe mensup bir yeniçerinin Üsküdar'daki Debbağhane'de çalıştığg ve o sırada Üsküdar'da bulunan yeniçeri kolluğunda 52. Bölüğe mensup yeniçeriler tarafindan kollandığını öğrenmekteyiz. (Câbî Târîhi 2003: c. I, 481) Bu bilgiler bize sadece olaylar bazında bir anlatı sağlamakla kalmamakta İstanbul'daki göç, hemşerilik ve iş ilişkileri ağları hakkında önemli bilgiler de içermektedir.

Özellikle Üsküdar kıyısındaki taşımacılık sektörünü ellerinde bulundurduğu anlaşılan 59. Bölük mensuplarının bu hâkimiyeti nasıl ele geçirdikleri konusunda bir bilgi bulunmamaktır. Ancak XIX. yüzyıl başlarında Üsküdar iskelelerinde kayıkçılık ve hamallık yapan esnafın büyük bir kısmının bu bölüğe üye olduğu anlaşılmaktadır. Daha da önemlisi en azından Üsküdar'da hamallık yapan 59. Bölük mensuplarının çoğunluğunun Tosya kazasından gelmiş olmasıydı. Tosya kazasından İstanbul'a göç edenler ile 59. Bölük ve Üsküdar hamalları arasındaki bağlantının ne zaman kurulduğu konusunda kesin bir bilgi yoksa da, daha XVIII. yüzyılın ilk yarısında Üsküdar sicillerinde Tosyalı bir hamal ile ilgili kayıta rastlanması bu ilişkinin yeni olmadığını göstermektedir. (Uçar 2004: 250)

Üsküdar'da yukarıda bahsedilen bütün siyasi çalkantılar yaşanırken Üsküdar iskelelerinde faaliyet gösteren hamalların başında kendisi de Tosyalı olan İbrahim Ağa isminde bir kethüda bulunmaktaydı. Aslında Üsküdar hamalları Kethüdası İbrahim Ağa’nın hikâyesi XIX. yüzyıl Osmanlı sosyal ve siyasi düzeni hakkında çok önemli ipuçları içeren bir örnek sunmaktadır. Tosya'dan gelip büyük ihtimalle hemşerilik bağlantılarını kullanarak hamallık yapmaya başlayan İbrahim'in 59. Bölüğe nasıl kaydolduğuna ilişkin bir bilgi bulunmamaktadır. Ancak burada da iş ya da hemşerilik ilişkilerini kullandığını düşünmek akla yakın gözükmektedir. 1787-1792 Harbi'nde kendisi de bir yeniçeri olan Şile ayanı Uzun Hasan maiyetinde harbe giden İbrahim, harp sırasında "turnacı" rütbesini almıştı. (Câbî Târîhi 2003: c. II, 750) Bu tarihten itibaren Ömer Câbî Efendi’nin anlat1mına göre hem gösterişli giyimi hem de kendisinden daha üst rütbede olması gereken ricale karşı takındığı laubali tavırlarla göze batmaya başlayan İbrahim Ağa 
bir anlamda mevcut sosyal statüleri zorlamaya başlamıştı. Câbî'nin seçkinci bir tavırla hamallık geçmişinden gelen ve altı üstü Üsküdar hamallarının kethüdası olan birinin bu tavırlarını hoş karşılamadığı anlaşılmaktadır.

Her ulufe dağıtımı döneminde 59. Bölük kışlasına giderek kendi ulufesi ile birlikte o sırada Tosya'ya gitmiş olan bölük mensubu hamalların da ulufelerini alan İbrahim Ağa'nın ilişki ağının son derece geniş olduğu anlaşılmaktadır. Bu hamalların hangi sebeple Tosya'da olduğu konusunda bir bilgi bulunmamaktadır. Kendi ulufesi dışındaki bu ulufelerin 300 kuruş gibi bir meblağ tutmasından çok sayıda yeniçerinin ulufesinden bahsettiğimiz açıktır. Bunların en azında bir kısmının esas sahibinin İbrahim A ğa olması ve çeşitli vesileler ile topladığı esâme kâğıtları vasıtası ile önemli bir gelire sahip olması o dönemki uygulamalar düşünüldüğünde ihtimal dâhilindedir. İbrahim Ağa'nın diğer bir gelir kaynağ ise Üsküdar iskelelerinde çalışan hamalların ücretlerinden aldığı paydı. Hatta Câbî’nin dile getirdiği bir şikâyet İbrahim Ağa'nın kethüdalığında Üsküdar hamallarının taşıma ücretlerine zam yaparak esnaf ve tüccardan fazla para talep etmesiydi. (Câbî Târîhi 2003: c. II, 749-751)

Sadece Şile ayanı ile değil memleketi olan Tosya'nın ayanı ile de irtibat halinde olan İbrahim Ağa her ne kadar tavırları ve giyimi ile mevcut sosyal statüleri zorlasa da bu sadece ricalin ve ricale yakın kesimlerin kınamalarına yol açacak küçük bir kabahatti. Câbî’nin anlatımına göre Kethüda İbrahim Ağa'nın sonunu getiren ise tabiri caiz ise boyundan büyük bir işe kalkıp Darphane-i Âmire'ye ait bir iltizamın iltimas ile birisine verilmesini sağlamak için Darphane Emini'ni tehdit etmesiydi. Bu tehdidi unutmayan Darphane Emini kısa bir süre sonra Kâimmakam atanınca İbrahim Ağa'nın idamını sağlamıştı. (Câbî Târîhi 2003: c. II, 755)

Yeniçeriler, Alemdar Vak'ası sonrasında siyasi güçlerini devam ettirseler de merkezi yönetim ölüm-kalım meselesi olarak gördüğü askeri reformdan vazgeçemeye niyetli değildi. Nizâm-1 Cedîd projesinin bu kadar uzun soluklu olması ve başarısızlıklara rağmen her seferinde yeniden yürürlüğe konmaya çalışılması bu projenin ricale mensup şu ya da bu isimle, hatta saltanatın başındaki sultan ile doğrudan alakalı olmayıp bir devlet projesi olduğunu akla getirmektedir. Alemdar Vak'ası sonrası bir süre daha yeniçerilerin tahkir ve tehditlerine maruz kalan 
II. Mahmud hükümeti bir taraftan da imparatorluktaki büyük ayanları birer birer tasfiye etmeyi başarmıştı. 1820'lerden itibaren de Yeniçeri Ocağı'nı yeniden hedefe alan merkezi hükümet özellikle önceki olaylarda önemli rol oynayan orta kademeli yeniçeri zabitlerini çeşitli bahanelerle ya İstanbul'dan uzaklaştırmış ya da ortadan kaldırmıştı. 1826'da da önceden hazırlanmış bir plan çerçevesinde yeniçerilere son darbeyi vurmuştu. Vak'a-yı Hayriye olarak isimlendirilecek olaydan ve onu izleyen cezalandırma sürecinden Üsküdar'daki yeniçeriler ve onları destekleyen gruplara mensup kimseler de payını almıştı.

II. Mahmud hükümeti Yeniçeri Ocağı'nı ortadan kaldırsa da uzun müddet yeniçerilerin yeniden bir harekete geçeceğinden çekinmiş, biraz da paranoyak bir biçimde her baktığı yerde bir yeniçeri tehdidi ve komplosu görmüştü. Tabii bunun en önemli sebebi yeniçerilerin topluma derinden nüfuz etmiş olması ve merkezi otoritenin bütün yeniçerileri cezalandıracak durumda olmamasıydı. İşte tam da bu ortamda bir kısmı yeni kurulmuş olan Asakir-i Mansure ordusu içine sızmış olan yeniçerilerin de içinde bulunduğu bir grubun isyan çıkarmak niyetinde olduğu ihbar edilmiş, büyük kısmı Üsküdar'da yaşayan Bektaşilerden ve mülga Yeniçeri Ocağı mensuplarından oluşan komplocular yakalanarak sorguya alınmıştı. Sorgu sonrasında bu ihbarın çok da aslı astarı olmadığı ve tutuklanan kimselerin ciddi bir tehdit oluşturmadığı anlaşılmış ama yine de bu işe ismi karışan 29 kişiden, ikisi tutukluluk sırasında hayatını kaybetmiş, on yedi kişi idam edilmiş, on kişi de sürülmüştü. İlgi çekici bir nokta olarak Osmanlı ordusunda yeni usullerin uygulanmasının bir nişanesi olarak suçlulardan Asakir-i Mansure ordusuna mensup olanlar Avrupa usulü kurşuna dizilmek suretiyle idam edilmişti. Geri kalan ve Üsküdar ahalisinden olan sivillerin ise idamları Üsküdar'da asılmak suretiyle gerçekleştirilmişti. (Uzunçarşılı 1943: c. I, 582-594) Bu siviller arasında bir Bektaşi şeyhinin ve müritlerinin bulunması bunların sorgularında o dönemim popüler inançlarını ortaya koyması açısından önem taşımaktadır. Remil, cifr ve rüya tabirlerinin de eşliğinde eli teberli on iki bin Bektaşinin kıble tarafından önce Üsküdar'a geleceği, sonra İstanbul tarafına geçerek Et Meydanı'na gidecekleri ve Yeniçeri Ocağı'nı ihya edeceklerine inanılıyordu. Bunların içinden Muhammed Ali isimli bir liderin çıkarak adalet ile hükmedeceği de bu inançlar arasındaydı. $\mathrm{Bu}$ hareketin askeri kanadını oluşturanların büyük kısmı ise mülga Yeniçeri 
Ocağı mensuplarıydı. Bunların bir kısmı 1826'daki isyana karışmadıkları için Asakir-i Mansure ordusuna dâhil edilen Boğaz kalelerinin yamaklarıydı. Diğer bir kesimi ise çoğu Üsküdarlı olan kalyoncu neferleriydi. Hareketin liderlerinden Üsküdar'da salı günleri âyin yaptırdığı için belgelerde Salı şeyhi olarak adlandırılan Şeyh Mehmed Efendi gözaltında iken zehir içerek intihar etmiş, bir diğer önemli isim olan mülga Yeniçeri Ocağı'nın 75. Cemaat'ine mensup Bektaşi dervişi Lüleci Ahmed hareketin askeri kanadını organize etmekte rol oynamıştır. (Uzunçarş1lı 1943: c. I, 584-586)

Tutuklananların sorgularından ortaya çıkan diğer önemli bir veri, bu tip hareketlerin nasıl ortaya çıtığı ve organize olduğu ile ilgilidir. Tamamen şifahi bir biçimde yayılan isyan ve mehdivari kurtuluş vaadi, ilişki ağları vasıtasıyla Yeniçeri-Bektaşi çevresindeki güvenilir kimselere yayılmış, haberlerin iletildiği kişiler ya bu hareketten uzak durmuşlar ya da isyan günü belli sayıda kişiyi beraberlerinde getirerek isyana katılacakları sözünü vermişlerdi. Ancak Sultan II. Mahmud'un da kendi hatt-1 hümayununda belirttiği üzere bu hareket ciddi bir tehdit oluşturmaktan uzaktı, zaten Sultan'a göre sorgulananların söyledikleri “deli saçmasından” ibaretti. (BOA, Hatt-1 Hümayun, nr. 289/17327; 290/ 17357, 340/19426)

XVIII. yüzyılın sonlarından itibaren başlayan Nizâm-1 Cedîd projesi yeniçerilerin ve onlara destek olan grupların muhalefeti sonucu ardı ardına iki kez başarısız olmasına rağmen merkezi yönetimin uluslararası arenada Osman1 Devleti'nin hayatta kalabilmesi için hayati önemde gördüğü askeri reform projesinin peşini bırakmadığı ve Alemdar Vak'ası sonrası iyice yıpranan yeniçerileri dikkatli bir planlama ve tasfiye süreci sonunda alt etmeyi başardığını görüyoruz. Bu sancılı sürecin bir yeniçeri semti olarak tanımlanabilecek Üsküdar'a olan etkisi de benzer biçimde tarihte derin izler bırakmıştır. Bu izlerin sadece bir kısmını ele alındığı bu yazıda Osmanlı toplumunun bir parçası olan yeniçerilerin ve yeniçeriliğin Üsküdar'daki son dönemi konu edilmiş ve bir anlatı doğrultusunda yeniçerilerin toplumsal, ekonomik ve siyasi rolleri üzerine tespitler yapılmaya çalışılmıştır. XVII. yüzyıldan XIX. yüzyıl başlarına değin geçen süreçte toplum yapısına derinden nüfuz eden yeniçeriliğin mensuplarına beraberinde getirdiği imtiyazlar ve ilişki ağlarının kuvveti merkezi yönetimin yeni bir askeri sistem 
kurmasına kolay kolay izin vermemiştir. Zira bu yeni sistemin kurulması Osmanlı toplumundaki sosyal statüleri ve sosyo-ekonomik ilişkileri derinden etkileyecek bir kapasiteye sahipti. Yeniçerilerin bu yeni sisteme direnişinin ardında yüzeysel biçimde ifade ettikleri dini-kültürel sebeplerden ziyade bu tehdidi doğru biçimde algılamaları yatıyordu. XIX. yüzyılın başlarında Üsküdar'da yaşanan olayların gelişiminde de yukarıda açıklanan faktörlerin rolü büyüktü. 


\section{Kaynakça}

T. C. Cumhurbaşkanlığı Devlet Arşivleri Başkanlığı Osmanlı Arşivi (BOA), Hatt-1 Hümayun, nr. 289/17327; 290/ 17357, 340/19426.

Aksan, Virginia (2007), Ottoman Wars 1700-1870: An Empire Besieged, New York: Routledge.

Beyhan, Mehmet Ali (2007), Saray Günlüğ̈̈ (1802-1809), İstanbul: Doğu Kütüphanesi.

Câbî Târihi: Târîh-i Sultân Selîm-i Sâlis ve Mahmûd-ı Sânî, haz. Mehmet Ali Beyhan, c. I, Ankara: Türk Tarih Kurumu, 2003.

Derin, Fahri Ç. (1975) "Yayla İmamı Risalesi," İstanbul Üniversitesi Tarih Enstitüsü Dergisi, 8/3: 213-272.

Georg Oğlukyan'in Ruznamesi: 1806-1810 İsyanları, III. Selim, IV. Mustafa, II. Mahmud ve Alemdar Mustafa Paşa, haz. Hrand D. Andreasyan, İstanbul: Edebiyat Fakültesi Basımevi, 1972.

Şânî-zâde Mehmed 'Atâ'ullah Efendi, Şânî-zâde Târîhi, haz. Ziya Yılmazer, c. I, İstanbul: Çamlıca, 2008.

Uçar, Ayhan (2004), “Üsküdar Mahkemesi’ne Ait 403 Numaralı Şer'iyye Sicili”, İstanbul, Marmara Üniversitesi Türkiyat Araştırmaları Enstitüsü (Yüksek Lisans Tezi).

Uzunçarşıllı, İsmail Hakkı (1943), Osmanlı Devleti Teşkilâtından Kapıkulu Ocakları, c. I, Ankara: Türk Tarih Kurumu.

Ünver, A. Süheyl (1969), “XVII'inci Yüzyıl Sonunda Padişah'a Bir Lâyiha”, Belleten, 129/ XXXIII: 21-34.

Y1ldı, Aysel (2008), "Vaka-y1 Selimiye or the Selimiye Incident: A Study of the May 1807 Rebellion”, İstanbul: Sabancı Üniversitesi (Doktora Tezi). 